\title{
«UN MONUMENTO AL ESCUPITAJO, ASESINO DEL BALLET»: IMPRESIONES, IMÁGENES Y PERVERSIONES EN TORNO A LA DANZA POR AGUSTÍN ESPINOSA*
}

\author{
Alejandro Coello Hernández \\ Instituto de Historia, CSIC
}

\section{RESUMEN}

La repercusión de la danza en la literatura durante la Edad de Plata ha sido poco atendida por la crítica, a excepción, sobre todo, de los casos más relevantes. Por ello, este artículo propone una relectura centrada en el estudio del arte coreográfico en la producción textual de Agustín Espinosa, tanto en sus artículos como en su obra literaria. De esta manera, se analizan las razones por las que se recurre a la danza, ya sea para ejemplificar, metaforizar o reflexionar. Por ello, se concluye que el autor acude a este hecho escénico para expresar su cosmovisión vital y estética, pues llega a elaborar un manifiesto personal fundamentado en la condena del ballet como expresión decimonónica. Espinosa se inserta, así, en las preocupaciones e intereses desarrollados por los intelectuales de la Edad de Plata en torno a la danza. Palabras Clave: Agustín Espinosa, danza, ballet, literatura, Edad de Plata.

\section{"UN MONUMENTO AL ESCUPITAJO, ASESINO DEL BALLET": AGUSTÍN ESPINOSA'S IMPRESSIONS, IMAGES AND PERVERSIONS ON DANCE}

\section{Abstract}

Critics have paid little attention to the impact of dance in the literature of the Silver Age, with the exception of the most relevant cases. For that reason, this article aims a re-reading focused on the study of choreographic art in the textual production of Agustín Espinosa, both in his articles and in his works. In this way, I analyse the reasons why he chooses the dance; for giving examples, writing metaphors and reflecting. Therefore, I conclude that the author writes about this performing act for expressing his world view about life and aesthetics, since he prepares a personal manifesto based on ballet's disapproval as nineteenth-century expression. So, Espinosa shares interests in dance along with other Silver Age's intellectuals. KeYwords: Agustín Espinosa, dance, ballet, literature, Silver Age. 
La danza, en sus diversas manifestaciones, adquirió durante la Edad de Plata un significativo espacio dentro de las creaciones literarias y de los artículos escritos por destacados autores de la época. La voluntad de recuperar danzas españolas y de reivindicar el flamenco como arte puro se mezcló con la fascinación por los nuevos ritmos traídos de Estados Unidos, como el fox-trot, el charlestón o el jazz. Por eso, muchos fueron los artistas que se cautivaron por la danza hasta tal punto que colaboraron estrechamente con coreógrafos y bailarines y compusieron dramaturgias para ballet, como son los casos de Cipriano de Rivas Cherif, Tomás Borrás, Mauricio Bacarisse o Felipe Ximénez de Sandoval. Dentro de una larga nómina, no se ha pormenorizado en un estudio del interés y uso de la danza que desarrolló Agustín Espinosa en su producción literaria y sus artículos publicados en prensa y revistas literarias. Es cierto que no se conocen datos precisos sobre la vinculación con personas del mundo dancístico, ni se ha localizado una dramaturgia suya para la escenificación mediante el baile, hecho que probablemente no llegue a producirse. No obstante, del análisis de estos materiales pueden obtenerse algunas conclusiones de los referentes que conoció y la dimensión ético-estética que proyecta sobre la danza para explicar su cosmovisión.

Como ya advirtió García de Mesa (2012: 440), los textos espinosianos se trazan por una teatralidad que genera una nueva visión del mundo. Sin duda, el tinerfeño participa de la renovación artística de las vanguardias a lo largo de toda su obra con una voluntad de llegar más allá de los límites y de los géneros, tal es el caso de su obra teatral La casa de Tócame Roque, que pone en práctica la «reteatralización» del teatro que defendieron artistas escénicos, en concreto después de la reflexión wagneriana de la obra total y las ideas expuestas por George Fuchs en $\mathrm{La}$ revolución del Teatro (1909). Más allá de su texto teatral, Espinosa jugó con la performatividad y la teatralidad a pesar de las limitaciones que impone lo literario a estas expresiones. Por tanto, su obra problematiza, desde el juego y la heterodoxia, con la propia palabra y con las representaciones del yo, desdoblado en ocasiones como en el artículo "Despedidas literarias de Agustín Espinosa. Una traición y dos historias»" Desde este enfoque, cabe plantearse qué interés directo existe hacia las artes escénicas, hacia las propuestas que suben al escenario con el objetivo de emanciparse de lo literario. Por tanto, la hipótesis de que Espinosa presta cierta atención a las artes escénicas ya desde su propia cosmovisión cobra sentido y resulta tan lógica como

* Este artículo es resultado de una ayuda del Ministerio de Ciencia, Innovación y Universidades (FPU19/00203) para realizar una tesis doctoral bajo la dirección de Idoia Murga Castro y Emilio Peral Vega. Asimismo, está realizado en el marco del proyecto de investigación P.E. I+D+i Tras los pasos de la Silfide. Una historia de la danza en España, 1836-1936 (ref. PGC2018-093710-A-I00), financiado por el Ministerio de Ciencia, Innovación y Universidades, la Agencia Estatal de Investigación y el Fondo Europeo de Desarrollo Regional de la Unión Europea.

${ }^{1}$ El artículo, según la edición de José Miguel Pérez Corrales que manejo, se escribió a finales de diciembre 1929 o a principios de enero de 1930. Su primera publicación se recoge en $L a$ Tarde, 17 de julio de 1980 . 
demostrable. Sin embargo, la huella que la danza imprime en su obra parece más difusa, así como se dificulta la posibilidad de concluir su verdadero interés en este arte.

\section{IMPRESIONES SOBRE LA DANZA EN LOS ARTÍCULOS ESPINOSIANOS}

Los artículos espinosianos dejan entrever, en las referencias dancísticas, la capacidad de este arte para definir una época. De tal manera que el ritmo y los movimientos de una danza en concreto se convierten en sinécdoque de la forma mentis de una sociedad concreta. La danza, por ende, desde la óptica de Espinosa, posee las cualidades necesarias para expresar el sentir y el pensar, lo que advierte una reivindicación implícita de esta disciplina como patrimonio inmaterial capaz de transmitir y corporeizar las ideas y la filosofía de un periodo. En definitiva, Espinosa hereda, en cierta medida, una visión de la danza tamizada por la teorización de los simbolistas, como Stéphane Mallarmé en sus Divagations (1897) o Paul Valéry en su L'Âme et la Danse. Dialogue socratique (1921) y posteriormente en Philosophie de la danse (1936), textos que bien pudo leer el tinerfeño, sobre todo en el caso de Mallarmé, cuyo Un coup de dés jamais n'abolira le hasard (1897) resuena en el título de la conferencia titulada Media hora jugando a los dados. En cualquier caso, estos poetas franceses reflexionaron sobre la sacralidad de la danza y su posibilidad de significar el alma a través del movimiento, como si los bailarines lograsen materializar lo abstracto e intangible, planteamiento de raíz platónica y socrática. En palabras de Mallarmé (1897: 178), «alors, par un commence dont paraît son sourire verser le secret, sans tarder elle le livre à travers le voile dernier qui toujours reste, la nudité de tes concepts et silencieusement écrira ta vision à la façon d'un Signe, qu'elle est». Es decir, la bailarina es un signo, y, como tal, revela una forma y un fondo relacionados con una sincronía. Cabe pensar, por ello, que la progresiva reivindicación e intelectualización de la danza en la primera mitad del siglo xx trajo consigo la dignificación del arte coreográfico y la participación de los bailarines en los círculos intelectuales, lo que generó trabajos conjuntos con escritores, músicos y pintores. Destacaría, quizá por la trascendencia de su papel en la danza, el caso de Cipriano de Rivas Cherif, quien en un artículo reflexiona sobre la evocación del pasado y la eternidad en los pasos de Antonia Mercé la Argentina, así como ensalza su talento para inspirar al resto de artistas (Rivas Cherif 1922: 2).

En definitiva, todo este ambiente rodea a Agustín Espinosa, quien tuvo probablemente conocimiento de estas cuestiones en sus estancias en Granada, Madrid y París, también debido a su erudición fruto de una avidez lectora. No obstante, desarrolla una visión más personal en la que se conjuga su defensa acérrima del ideario vanguardista, como se estudia a continuación. Así pues, sus escritos reflejan esa idea de la danza como sinécdoque. En su conocido «Elogio de la burbuja»" diversos bailes

2 Publicado el 23 de abril de 1931 en La Tarde y el 15 de junio de 1931 en La Gaceta Literaria, n. $^{\circ} 108$. 
se entremezclan en las enumeraciones, tanto del pasado como del presente, con las que el autor pretende hacer un adarve del cine y, por consiguiente, de la modernidad. Contrapone lo contemporáneo con la actitud de una mayoría que perpetúa aspectos antiguos y anquilosados de una sociedad en decadencia:

En el siglo del cinema y del jazz, del avión y del "pullover», del rascacielo[s] y del deporte, del cubismo y de la radiofon[í]a, evocar giros de minué, compases de mazurca, relojes de cuco, pasos de andadura, serenatas de organillo, chisteras y piróscafos, coches de posta y bigotes de Campoamor (Espinosa 2017: 112).

El tinerfeño concluye su crítica contra esta actitud con una máxima de gran expresividad: «Pontificar la polka a la hora del "charlestón”» (Espinosa 2017: 112). Esta idea de bailar a otro ritmo opuesto al del momento se repite en su artículo «Una hora arqueológica de España. Trajes de época, danza vetusta y ecoica canción ${ }^{3}$, en donde vuelve sobre el motivo de una danza perteneciente a otro periodo como metáfora de aquellos que celebran con valores arcaicos y desfasados el triunfo de la Segunda República un año después de la proclamación en 1931. La misma estrategia se reitera en el artículo "Madrid desde Canarias, Canarias desde Madrid»" , en donde se concibe a Canarias desde Madrid como «una tribu entretenida en bailar sus danzas circulares, inexplicables, mediocres» (Espinosa 2018a: 183). En este caso, la danza vuelve a funcionar como un mecanismo de reconocimiento y definición de una sociedad, como expresión que sintetiza la mirada exótica y turística de quien mira desde fuera, como ejemplo de "un sueño colonial con gaviotas y azahares» (Espinosa 2018a: 183) para el deleite y la felicidad de quien mira desde Madrid.

Los usos retóricos que Espinosa elabora en torno a la danza a lo largo de su producción textual, no obstante, son aún más diversos y de mayor complejidad. Sin duda, uno de los textos más destacados en ese sentido es el artículo «1557$1927{ }^{5}$, en donde la prosa se funde con la evocación poética. En él, la escritura parece más semejante a la de su obra literaria. El escritor elabora el texto a partir del décimo séptimo decenario de la victoria española en la Batalla de San Quintín, lo que produjo la construcción de El Real Monasterio de San Lorenzo de El Escorial. La elección de este santo por parte de Felipe II se debió al día triunfal, el 10 de agosto, en que se celebra la festividad de San Lorenzo. Esta decisión se reflejó en la planta del edificio que su arquitecto, Juan de Herrera, concibió de tal manera para que evocara la parrilla en que martirizaron al santo. Toda esta cuestión históricoreligiosa se canaliza a través de la voluntad poética del escritor. De esta manera, se explica la conceptualización dancística en torno al edificio histórico porque "para el exaltador de decenarios queda la cantera folklórica. La leyenda supersticiosa. El balé trágico de El Escorial: la Danza del Fuego» (Espinosa 2019: 190). En este momento, el movimiento del fuego, de gran expresividad balletística, se junta con

\footnotetext{
${ }^{3}$ Publicado el 14 de abril de 1932 en Crónica.

4 Publicado el 31 de diciembre de 1932 en La Tarde.

5 Publicado en La Rosa de los Vientos, n. ${ }^{\circ}$ 4, diciembre de 1927.
} 
una referencia capital dentro de la historia de la danza en España: El amor brujo. Se conecta el pasaje del santo y la simbología arquitectónica con el número más destacado del ballet, en que la gitana Candelas baila alrededor del fuego para evocar los espíritus buenos para su causa amorosa. Precisamente esta leyenda de superstición se imbrica con la danza y permite a Espinosa jugar con la referencia. Cabe suponer que conoció, al menos, la composición de Manuel de Falla, a quien loa en algunos artículos. Por intuición, se puede concluir que el prosista no disfrutó de la gitanería, estrenada en 1915 por Pastora Imperio, sino que tal vez conoció el ballet estrenado en 1925 resultado de la colaboración tan fructífera de Manuel de Falla y María Lejárraga, quienes realizaron algunos cambios dramatúrgicos y musicales. No obstante, en esta ocasión fue coreografiada y protagonizada por Antonia Mercé la Argentina, bailarina que curiosamente nunca menciona el tinerfeño. Continúa el texto con una evocación de ese mundo supersticioso propio de los ballets de la época en que el fuego danza en sus ondulaciones:

La Danza del Fuego. (Danza del cuerpo rojo del Santo emparrillado. Danza del cuerpo verde del sodomita. Danza de las campanas de la torre ejemplar.) La Danza del Fuego. (Danza de Felipe II. Danza de los monjes supersticiosos.) La Danza del Fuego. (Y fluye la música canida del perro embrujado del naciente Marqués.) (Espinosa 2019: 190).

Esta visión del fuego estrechamente vinculado con la danza reapareció, casi una década después, en la conferencia «La isla Arcángel de Lope», impartida el 21 de octubre de 1935 en el Instituto de Estudios Canarios, cuya conservación es parcial según comenta en su edición José Miguel Pérez Corrales. En primer lugar, en el capítulo «Brasa», escribe: "Tiene la hoguera un corazón. Tiene cabellos. Tiene ojos y brazos. A su alrededor aúlla el viento. La hoguera es la única bailarina que no pone piernas a sus danzas» (Espinosa 2018b: 129). Luego describe la hoguera y la brasa como signos que identifican al fénix de los ingenios por su ardor amoroso. A continuación, en el capítulo «Fuego», Espinosa cierra la idea con el axioma recurrente: «Fuego. Lope de Vega es fuego» (Espinosa 2018b: 130). En cualquier caso, la codificación del fuego como bailarina o coreografía natural refuerza la imagen, que es parte del inconsciente colectivo y que se fortaleció probablemente por la creación del maestro Falla y la escritora Lejárraga.

Los imaginarios que desde la danza se crean a partir de conceptos como la españolidad se cuelan también en los artículos espinosianos y, de nuevo, sirven de símiles para entender el asunto sobre el que diserta. Este es el caso de la reseña «Antonio Ruiz (La vida extraordinaria del campeón de Europa)»", en donde el autor reflexiona sobre el libro escrito por el periodista Ramón de la Serna. La similitud del nombre con el del padre de la greguería lleva a Espinosa a confundirlos y, fruto de la equivocación, establece una relación entre el boxeador vallecano con el torero de Ramón Gómez de la Serna, que aparece en su novela El torero Caracho. Téngase

\footnotetext{
${ }^{6}$ Publicado en La Rosa de los Vientos, n. 3, junio de 1927.
} 
en cuenta que esta novela se publicó un año antes que el texto sobre Antonio Ruiz, lo que quizá también propició la confusión del autor. En cualquier caso, la reseńa continúa reflejando el conocimiento balletístico del autor, que concluye que la biografía del boxeador se ambienta con «la música y la decoración, dignas del ballet de que es heroína la "pepona"» (Espinosa 2019: 166). Esto es, el ambiente marinero, en donde personajes de toda índole participan de la venta ambulante, en donde al fondo una "pepona" está encerrada en un balcón, según la descripción imaginativa que realiza Espinosa a partir de la lectura, recuerda sobremanera a algunos ballets, como a Los marineros (1925) de los Ballets Russes de Diaghilev y en especial al texto inédito El desertor (1930), de Felipe Ximénez de Sandoval7. Es más, se describe al boxeador como un torero, personaje recurrente en las dramaturgias españolas para ballet: «Trajeado polícromamente lo hemos visto agitarse en la malla nueva de un ballet ruso (En Petruchka -riqueza, atrevimiento- de Strawinscki [sic].) Por eso, necesitaba nuestro torerillo decoración y música de ballet» (Espinosa 2019: 165). Más allá de la imagen, explícita, llama la atención directa al ballet Petruchka de los Ballets Russes de Diaghilev, que se representó en España en su gira en 1916. Espinosa se ve también influido por la alargada huella de los Ballets Russes ${ }^{8}$, cuya impronta en la renovación escénica es de sobra conocida, lo que acentúa la importancia del arte coreográfico en la primera mitad del siglo xx.

De nuevo, en una reseńa el autor despliega su quehacer literario y recurre a las posibilidades retóricas del ballet para metaforizar la relación establecida entre el poeta, Andrés de Lorenzo-Cáceres, y San Marcos, playa de Icod de los Vinos, en su cuaderno El poeta y San Marcos (1932). Es más, la fuerza expresiva de la imagen ocupa un lugar central ya en el título del texto: «El poeta en San Marcos. "Ballet" de un estío recién quemado»". El descubrimiento de la playa icodense por el poeta se describe como el proceso de memorización de una coreografía: «Aprendiendo el número marino, allá, en una playa con norte» (Espinosa 2018a: 217). Luego, continúa desplegando la metáfora del poeta-bailarín que se acompaña de San Marcos, con la que se establece un juego dialógico en que a veces es playa y a veces santo. Espinosa, que combina la versificación con la prosa en este texto, desarrolla con precisión la imagen balletística como el proceso de inspiración del paisaje sobre el creador cuando escribe: «El poeta y San Marcos fueron algo más que el Poeta y su Musa. Fueron el poeta y su pareja de baile. No fue, no, "así" como escribió A. de Lorenzo Cáceres su cuaderno de estío. No fue "así". Sino bailando con San Marcos. Al compás de los pies del santo de palo" (Espinosa 2018a: 218). Como cierre, se compara al poeta con Gonzalo de Berceo, porque "tu "ballet" con San Marcos es el mismo docentista "ballet" que vigió sus bailares. Como tú danzas hoy danzaba ha 7 siglos el clérigo seglar de los acaeceres desmayados» (Espinosa 2018a: 218).

7 Sobre la dramaturgia inédita de Ximénez de Sandoval, véase Coello Hernández (2019).

${ }^{8}$ Para más información acerca de la importancia del ballet ruso y sus derivas en la prensa y las revistas de la Edad de Plata, véase Martínez del Fresno (2016). Para una visión general pero detenida sobre los Ballets Russes, consúltese Álvarez Cańibano y Nommick (2000).

9 Publicado el 4 de abril de 1933 en La Tarde. 
Otro modo de aparición de la danza en los artículos espinosianos es la mención a bailarines que, desde el punto de vista expresivo, no suele adquirir un valor destacado, aunque estos datos sí nos permiten afirmar su conexión con la época y sus referencias de novedades escénicas, como ocurre con su reflexión crítica sobre la influencia teatral del serafismo ${ }^{10}$ en "Cocteau en España. Diario de una europeización»". Como bien reclama el autor en su artículo "Salutación al sabio»" con motivo de la llegada del antropólogo Dominik Josef Wölfel a Tenerife, si le hubiesen encargado una entrevista, «hubiera hecho de D.J. Woefel la interviú solemne que otros hacen a bailarinas o presidentes de repúblicas, príncipes o políticos» (Espinosa 2918a: 196). No deben extrañar, por ello, las menciones que a continuación se analizan, pues algunas bailarinas eran de sobra conocidas. Es más, Tomás Borrás sintetiza esta común inspiración que poetas y dramaturgos reciben directamente de estas artistas, pues

cuando el Teatro, bien domesticado, bien desvirtuado, bien desgalichado, bien aniquilado estaba exánime, repelente, empezaron a surgir las bailarinas. Las bailarinas empujaron con el hociquito de la punta de sus pies las puertas lacradas. [...] Entró en escena un sol desinfectante, un oxígeno de perfumes: lo imaginativo, lo alado, lo despreocupado, lo desnudo, lo plástico, lo fantástico (Borrás 1931: 13).

En estas coordenadas, se ha de señalar el ya citado «Despedidas literarias de Agustín Espinosa. Una traición y dos historias», en donde el autor se realiza una entrevista a sí mismo y, fugazmente, se alude a una bailarina: «Yo, por un momento, intento ser interviuvador clásico. Tengo en una mano el haz de cuartillas. En otra, la pluma faqueral con que he matado, hace unas horas, a la hija de Rasputín, esa bailarina con aires de osa» (Espinosa 2019: 286). El tinerfeño critica a María Rasputín, hija del célebre ruso, quien aprovechó la fama del caso de su padre y el interés mediático del ballet ruso y las varietés para realizar una gira europea. Según la prensa, debutó en el Teatro de la Zarzuela el viernes 13 de diciembre de 1929 y estuvo programada hasta el 15 del mismo mes. Las críticas apuntan su falta de técnica, de la que se hace eco en estas líneas Espinosa. Cabe la posibilidad de que el prosista hubiese visto algún espectáculo de la bailarina, pero desconocemos más datos. Asimismo, en «Un reportaje super-realista» ${ }^{13}$, un relato hilarante que se finge reportaje antropológico, se describe a una jovial muchacha de quince años, Isabel, como «una serrana de transición de las del Arcipreste a las del Marqués [de Santillana]» (Espinosa 2018b: 221) y a su caminar como «donairoso girar, ágiles saltos rítmicos de fuga, vesánico galopar: Clotilde Sakharoff en la Bacante glazu-

10 «Serafismo» fue la denominación acuñada por Ramón Gómez de la Serna para señalar la vertiente vanguardista que inauguran Jean Cocteau y sus acólitos. La definición puede rastrearse en Gómez de la Serna (1931).

${ }_{11}$ Publicado el 1 de octubre de 1931 en La Prensa.

12 Publicado el 24 de enero de 1933 en La Prensa.

13 Texto inédito que recoge Pérez Corrales en las ediciones que tomamos de referencia. El ínclito investigador lo fecha en la etapa de la revista La Rosa de los Vientos, esto es, entre 1927 y 1928. 
nowiana» (Espinosa 2018b: 221). Sakharoff fue una reputada bailarina renovadora de la escena que llegó a colaborar con el conocido director teatral Max Reinhardt, que tanto influyó al teatro español de la época.

De mayor interés parece la referencia a Vicente Escudero, quien revolucionó el flamenco a finales de la década de los veinte con Variations acompañado de castanuelas de plata, hierro y aluminio y Ritmos solo con la música de su zapateado y el ritmo de unos motores. La curiosidad, sin duda, reside en que Espinosa lo nombra para ejemplificar una de las preguntas realizadas por La Gaceta Literaria ${ }^{14}$ sobre cómo ha entendido el entrevistado el concepto 'vanguardia'. Sentencia el tinerfeño: «Indudablemente, hay una magnífica sinonimidad entre los términos vanguardia y ventaja. Cuando decimos: Vicente Escudero es un bailarín de vanguardia, adjetivamos en ese sentido" (Espinosa 2017: 31). Sin duda, las relaciones entre vanguardia y danza en España problematizan teóricamente, sobre todo en casos como los de Antonia Mercé la Argentina o Encarnación López Júlvez la Argentinita, cuyas estéticas no se ajustan quizá a algunos preceptos vanguardistas que sí definen la música, la escenografía o el figurinismo que las acompañaba, fruto de su relación con los artistas en boga del momento ${ }^{15}$. Frente a este caso, Vicente Escudero experimentó con el movimiento y con ritmos y sonidos nuevos, diferentes, una innovación que recuerda, por ejemplo, a los «intonarumoris» de la música futurista. Jugó con la plástica de su cuerpo a la manera cubista porque «del cubismo me interesaba sobre todo la coincidencia con una gran preocupación mía: conseguir el equilibrio estético entre cada una de mis actitudes con una total despreocupación por todo lo que perciben y deforman directamente los sentidos» (Escudero 1947: 109). Espinosa, probablemente conocedor de los ensayos dancísticos de Escudero en el Théâtre Courbe en París, también se interesó por el cubismo, que se cuela en las páginas de su Lancelot, $28^{\circ}-7^{\circ}$.

\section{IMÁGENES SOBRE LA DANZA EN LA OBRA ESPINOSIANA}

La producción literaria de Espinosa se encontrará también impregnada en algunas ocasiones de imágenes y alusiones relacionadas con la danza que, como ya se ha advertido, formaba parte del acervo cultural a la par que demostraba cuán actualizados estaban los intelectuales del momento. Por esa razón, indagar en las piezas espinosianas arroja aún más datos de la vinculación del tinerfeño con el arte coreográfico.

Sin duda, en la pionera publicación de Lancelot, $28^{\circ}-7^{\circ}$ en 1929 también se filtra la huella dancística de una manera aparentemente insustancial, como en los artículos. Por un lado, en el capítulo «Biología del viento de Lanzarote», se emplean

14 «Una encuesta sensacional: ¿qué es la vanguardia?» fue publicado en La Gaceta Literaria en julio de 1930, n. ${ }^{\circ}$ 85, pp. 3-5. El testimonio de Agustín Espinosa se recoge en la página 4.

15 Sobre esta cuestión, consúltese el capítulo «Vanguardia y modernidad entre el ballet clásico y el español (1925-1930)» en Murga Castro (2017: 117-190). 
varias imágenes relacionadas con la danza. De nuevo, dentro de una larga tradición, se conceptualiza al viento, al igual que se ha señalado con el fuego, como un número coreográfico, de tal suerte que la mirada dancística se superpone sobre el viento con la intención de metaforizar y a la vez dar vida al elemento natural con una pretensión degradante o humorística, como el viento lanzaroteño que puede «enterrar camellos con solo dos giros de su danza desértica» (Espinosa 2019: 42). Asimismo, el viento, como en «Preciosa y el aire» de Federico García Lorca, se propone ir a molestar a Espinosa, otro alarde metaficcional del autor, mientras escribe sobre su existencia y, en ese momento, «entra por la ventana entreabierta de la habitación n. 5 del Hotel Oriental de Arrecife y dirige el ballet de las cuartillas que Agustín Espinosa escribe sobre tus dolorosos valores» (Espinosa 2019: 46). Este tipo de imágenes adquiere un gran poder visual gracias, sin duda, a la teatralidad del hecho escénico que supone la danza.

En «Final», despunta la écfrasis de un cuadro titulado Ánimas, pintado por Antonio de la Cruz y conservado en la iglesia de Tinajo de Lanzarote. En esta ocasión, el escritor concibe una sugestiva relectura de la muerte del Diablo por san Miguel Arcángel: «No sólo Purgatorio. Sino también Infierno. San Miguel baila el charleston sobre la barriga del Diablo. Lección para Josefina Baker» (Espinosa 2019: 114). La mención a la aclamada bailarina estadounidense no resulta baladí si se valora que la primera gira que realizó en España comenzó en las primeras semanas de febrero de 1930, cuando ya se había editado Lancelot, $28^{\circ}-7^{\circ}$. Por tanto, Espinosa tuvo que conocerla con anterioridad, probablemente a través de alguna grabación. Se ha de valorar que Baker no aparece mencionada en la misma imagen publicada en marzo de 1929 en el artículo "Óptica de Agustín Miranda " ${ }^{16}$, que termina una evocación festiva del poeta, en la que Gómez de la Serna dirige un charlestón, con las siguientes palabras: "Como el "San Miguel" de Antonio de la Cruz, baila sus danzas fervorosas sobre el cuerpo caído - gorilesco- de Satanás» (Espinosa 2019: 229). La teoría sobre la grabación de Baker se refuerza si se tiene en cuenta que el prosista formó parte del cineclub de La Gaceta Literaria y que había residido hasta 1924 en Madrid como posible explicación a esa variación textual del artículo a Lancelot, $28^{\circ}-7^{\circ}$ y a su conocimiento sobre la existencia de la bailarina. Muchas plumas fueron las que idealizaron a "la diosa de ébano», también españolas, entre las que destacaría el particular caso de Tomás Borrás, quien en 1931 publica Tam tam, un libro consagrado a la fascinación por la danza. En él, el dramaturgo madrileño la describe como «bailarina salvaje, dirección inédita» frente a Antonia Mercé la Argentina y lo popular, Tórtola Valencia y lo dramático, Lillian Roth y lo humorístico y Ana Pavlova y lo literario/teatral, sobre la que volveremos más tarde. Borrás elogia su figura por su actualidad, por constituirse, en definitiva, como signo de la modernidad: «Ella viene a renovar la civilización gastada, el arte artificioso: es como la danzarina del tótem cuando se funda una ciudad nueva» (Borrás 1931: 23). Precisamente, estos aires de novedad y subversión fueron los mismos que cautivaron a Agustín Espinosa.

16 Publicado el 30 de marzo de 1929 en El País. 
En Poemas a Mme. Josephine, una compilación escrita antes de 1932 e inédita hasta los ochenta, se recoge también una imagen dancística. En concreto, en el primer poema se reinventa a Baco según las coordenadas contemporáneas del autor, como si estuviese bajo el signo de Baker. De hecho, Espinosa vuelve a la estrategia utilizada en algunos artículos: emplea la danza, junto con otros elementos enumerados, como sinécdoque de una época. En este caso, se refleja la modernidad en unos versos que aparecen tachados en el original: «Mr. Bacchus: eglógrafo puro: / gran barman mitológico: / dancing-máster / internacional» (Espinosa 2018b: 225).

Su pieza de mayor trascendencia escénica, sin duda, es La casa de Tócame Roque, que escribió el autor en 1934. La historiografía teatral ha concluido que se trata de la única pieza de verdadera factura surrealista junto al Hamlet (1927), de Luis Buñuel y Pepín Bello. Ya desde el título la obra resulta sugerente, pues se basa en una casa llena de bullicio que aparece en el sainete costumbrista de Ramón de la Cruz La Petra o la Juana o el buen casero, que se ubicaría en el final de la actual calle de Barquillo en el centro de Madrid. Esta inspiración pretendida en el dramaturgo madrileño del siglo xviII desvirtúa el sentido original al llevar el hipotexto a los ejes temáticos y estéticos del surrealismo; sin embargo, a la vez, se asemeja a los intereses neopopularistas de sus coetáneos. Un caso particular lo ejemplifica Cipriano de Rivas Cherif al concebir la dramaturgia del ballet El fandango de candil, que evoca un sainete homónimo de Ramón de la Cruz, que interpretó y coreografió Antonia Mercé la Argentina en sus Ballets Espagnols con decorados y figurinismo de Néstor de la Torre y música de Gustavo Durán. No obstante, los caminos que continúan Rivas Cherif y Espinosa pueden clasificarse como opuestos. Habría que señalar, como nota curiosa, que el título espinosiano quizá haya partido de la novela de Ramón Ortega y Frías, La Casa de Tócame Roque o un crimen misterioso, que surgió del sainete, y lo que propició la creación de una zarzuela homónima con libreto de Javier Santero y música de Manuel de Falla, cuya contribución al ballet resulta insoslayable. En resumidas cuentas, las artes escénicas se vinculan con la producción del canario de una manera más profunda de lo que parece a primera vista.

En la obra teatral de Espinosa, llama la atención la advertencia que cierra la primera escena «Habla un altavoz», previa al prólogo. El tinerfeño indica su preferencia en cuanto a la música que ha de acompañar al monólogo del altavoz, que debería estar "compuesta por una rápida sucesión de motivos de las piezas musicales populares más representativas del primer tercio de siglo» (Espinosa 2018b: 250). Por un lado, el altavoz recuerda al que lleva incorporado a su vestuario el personaje del Mánager americano, según los bocetos picassianos, en su anunciamiento del desfile en el ballet Parade (1917) de los Ballets Russes de Diaghilev y también a los fonógrafos empleados por Jean Cocteau en Los novios de la Torre Eiffel (1921). Por otro, la música del primer tercio evocaría en el público, sin duda alguna, los bailes asociados a ella, si hubiera llegado a representarse. Por otro lado, ya en el tercer acto, cuando Juan le comenta a Julio el carácter trágico que rodea a la casa, le revela entre los hallazgos que ha hecho el jardinero Benedicto (recuérdese que Los hallazgos macabros es el título de la obra que ha escrito el protagonista) «una cabeza de adolescente maravillosamente cercenada, como si acabara de pasar por su cuello la cuchilla de una guillotina, y un pie de mujer, pintado y maquillado como el de una bailarina 
de Ópera» (Espinosa 2018b: 266). En esta ocasión, se observa una degradación del ballet que ya había formulado en 1931 en su artículo "Manifiesto rojo de una era en Aries. Adiós al ballet $»^{17}$, sobre el que nos detendremos en el siguiente epígrafe. La idea de bailarina finisecular, que había sido idealizado por Mallarmé o Valéry, se convierte en un signo más de un mundo elitista, de raigambre decimonónica, de valores burgueses. En definitiva, el ballet era un símbolo más de la decadencia de Occidente, como lo denominó en 1918 el filósofo alemán Oswald Spengler.

En su magna obra, Crimen, el surrealismo inunda la novela con destellos poéticos. Destaca, para nuestro análisis, «Parade», en donde un desfile de clowns y asesinos pasan delante del poeta. Este capítulo evoca el título del ballet homónimo previamente mencionado, cuyo libreto estuvo a cargo de Jean Cocteau, la escenografía y el vestuario a cargo de Pablo Picasso y la música en manos de Erik Satie. Si bien se estrenó el 18 de mayo de 1917 en el Théatre du Châtelet, llegaría el 16 de junio del mismo ańo al Teatro Real de Madrid, lo que permite afirmar que «el cubismo de Picasso llegó antes a Madrid a través de la danza, en forma de escenografía y vestuario, que a través de los lienzos de las exposiciones al uso, y solo los más avezados supieron darse cuenta de la trascendencia de aquella representación en 1917» (Murga Castro 2017: 42). En este punto, cabe preguntarse si Espinosa pudo asistir o tener noticia de este ballet porque, de lo que no hay duda, es de que conoció bien tanto la creación picassiana como la trayectoria de Cocteau y su repercusión en la literatura y el teatro españoles, como demuestra en su artículo "Cocteau en España. Diario de una europeización». Once días antes, el día 5, se realizó un homenaje a la figura de Picasso de la mano de Ramón Gómez de la Serna en el conocido café Pombo, entre cuyos asistentes aparece «Espinosa» (Heraldo de Madrid 1917), que podría corresponderse con el tinerfeño, que en aquel momento residía en Granada y no se instalaría en Madrid hasta 1919.

\section{PERVERSIONES DANCÍSTICAS: DEL MANIFIESTO ANTIBALLETIANO AL TANGUISMO}

Llegados a este punto, en donde se ha revisado una buena parte de los artículos y la obra literaria de Agustín Espinosa, este estudio carece de un análisis pormenorizado de los textos que, aun así, permite dibujar una mirada u opinión más concreta del autor sobre el hecho escénico. Por esa razón, en este epígrafe, se reflexiona sobre cómo se inserta la danza dentro de la cosmovisión espinosiana y de la definición de su poética. En este apartado, como se constata a lo largo del artículo, se observa una degradación continuada de la danza escénica, en concreto del ballet, por ser una forma dancística que recorre los circuitos oficiales y comerciales. A ello se suma ese proceso continuado de metaforización propio del arte de las vanguardias que, como bien expresó Ortega y Gasset en La deshumanización del

\footnotetext{
${ }_{17}$ Publicado el 4 de abril de 1931 en Proa, n. ${ }^{\circ} 1$.
} 
arte (1925), tiende a «un raro predominio de la imagen denigrante que, en lugar de ennoblecer y realzar, rebaja y veja a la pobre realidad» (Ortega y Gasset 2009: 104).

De todos los textos espinosianos, el artículo "Manifiesto rojo de una era en Aries. Adiós al ballet», anteriormente citado, cobra una especial relevancia para nuestro estudio. Los investigadores que se han acercado a la figura del tinerfeño han destacado la importancia de este texto dentro de su trayectoria, pues, después del manifiesto de La Rosa de los Vientos ${ }^{18}$ y antes de los diversos manifiestos de la puntera Gaceta de arte ${ }^{19}$ (revistas de las que formó parte el escritor), este supone su único manifiesto personal. Además, según José Miguel Pérez Corrales (Espinosa 2017: 106), iba a integrar un proyecto de libro bajo el título Óptica de un sueño perdido al que se sumarían los primeros escritos publicados en La Rosa de los Vientos. En cualquier caso, este texto, que vio la luz diez días antes de la proclamación de la Segunda República española, advierte el cambio de ciclo dentro de la estética del autor más tendente al surrealismo y a la subversión. Supone, a mi modo de entender, el cambio de sensibilidad y pensamiento que explica por qué, en apenas cinco ańos, Espinosa concibe dos obras tan dispares y capitales de la vanguardia insular y nacional como Lancelot, $28^{\circ}-7^{\circ}(1929)$ y Crimen (1934).

El título del artículo resume en sí mismo la actitud contestataria del autor y su voluntad de hacer pública su particular visión. El color rojo encierra, para la época, una posición ideológica asociada al comunismo, aunque también «le rouge est donc pour Espinosa une sorte de code d'accès, étant données les similitudes entre la symbolique de cette couleur et la personnalité de l'écrivain» (Gómez Gutiérrez 2008: 545). A continuación, la «era de Aries» puede evocar varias cuestiones. En primer término, la fecha de publicación, el 4 de abril de 1931, se corresponde con la época de ese signo zodiacal. En segundo lugar, remite a la fecha de nacimiento del autor, el 23 de marzo de 1897, lo que reafirmaría su necesidad de construirse un ideario ético y estético propio. En tercer término, según Gómez Gutiérrez (2008: 545-546), la elección del carnero también reforzaría el ardor del rojo, puesto que este es el color asociado a él. Por último, la misma investigadora señala lo sugerentes que resultan las reminiscencias al dios griego de la guerra: Ares; lo que explica la exposición pública y militante que hace Espinosa de sus propias ideas.

El manifiesto se vertebra a partir de una sentencia recurrente, disgregada por todo el texto: "Se ha acabado el reino del "ballet"». Con este comienzo, Espinosa sienta las bases de su particular visión del arte y de la vida, de la defensa de una estética que se impone a lo que representa para él este género dancístico. Una de las claves interpretativas se fundamenta en la visión del ballet como una expresión decimonónica, lo cual resulta discutible para la propia historia balletística en España, pues per se el primer proyecto íntegramente español con voluntad de nacio-

${ }_{18}$ El «Primer manifiesto de La Rosa de los Vientos» se publicó el 1 de febrero de 1928 en La Prensa, en la primera página.

${ }^{19}$ La revista tinerfeña publicó diversos manifiestos grupales, entre los que destacamos, dada nuestra relación con la escena, el «10 manifiesto de g.a. Tema: contra el actual teatro español», recogido en el número 21 de noviembre de 1933 en la página tercera. 
nalizar el ballet con éxito siempre fuera de España lo conforman los Ballets Espagnols de la Argentina entre 1927 y 1929 con los antecedentes de El sombrero de tres picos de 1919 de los Ballets Russes (música del maestro Falla, libreto de María Lejárraga y decorados de Picasso) y El amor brujo de 1925 (revisión balletística de la gitanería de 1915 protagonizada por la Argentina, Vicente Escudero y el mimo George Wague).

No obstante, Espinosa proyecta sobre el ballet una visión heredada del romanticismo etéreo de las Sílfides, más en conexión con el repertorio ruso que tanto gustó en España, y define al género balletístico como "un extracto de "Romanticismo para personas de buen gusto". Tenía aire de ensueño vago. Y todo lo alado y cefírico de la peor literatura y de la peor pintura sin reposo" (Espinosa 2017: 103). Aunque durante las vanguardias se revisitó el movimiento de la primera mitad del siglo XIX, como advierte el título del poeta icodense Emeterio Gutiérrez Albelo Romanticismo y cuenta nueva (1933) o el capítulo «La Nochebuena de Fígaro» en homenaje a Larra de la magna obra espinosiana Crimen, el escritor condenó esta vertiente del romanticismo laxo que terminó siendo asumido por el melodramatismo finisecular, cuyo máximo representante es el Nobel José Echegaray. En cualquier caso, Espinosa vuelve a las mismas estrategias que ya se han señalado con anterioridad como si se tratara de un silogismo: si el ballet es decimonónico y lo decimonónico expresa una cosmovisión sociopolítica y económica en decadencia en la primera mitad del siglo xx, entonces el ballet encierra esa mirada excluyente, elitista y capitalista que rechaza tajantemente el tinerfeño. Es más, se conceptualiza el ballet como una expresión rusa fruto del zarismo, que había sido revocado con la Revolución rusa de 1917. Afirma, por ello, que la pervivencia del ballet se identifica con «la última sonrisa del Zar moribundo, vestido de oro y martas bajo los cuchillos del proletariado» (Espinosa 2017: 104).

Según este esquema subyacente al planteamiento espinosiano, Ana Pavlova se convertiría en un ejemplo concreto y trascendente, pues quizá sea la bailarina de ballet ruso con mayor proyección y reconocimiento internacional en la primera mitad del xx. Es más, el poeta y ensayista Juan Gil-Albert publicó en 1930 un artículo titulado "Ana Pavlova. Último baluarte del zarismo" en La Gaceta Literaria, que refleja el mismo ideario político que proyecta Espinosa tan solo un ańo después, al que suma la defensa que supone Pavlova del «arte por el arte», presupuesto puesto en juicio por algunos vanguardistas cercanos a ideologías izquierdistas. Según Gil-Albert (1930), «el arte de la Pavlova rezuma el hedor exquisito y malsano de la Santa Rusia imperial. Un arte dogmático de cánones fijos. Las danzarinas, como los metropolitanos, esclavos del protocolo; ¡todo por el zar!». Estas dos visiones contrastan con la entusiasta explicación que hace Tomás Borrás sobre la bailarina, clasificada como «bailarina literaria, tradición teatral» (Borrás 1931: 19). En cualquier caso, la visión de Borrás engarza con la de Espinosa en que ambos señalan lo literario que expresa Pavlova, eso sí, desde una óptica positiva y una negativa, respectivamente. De hecho, el tinerfeño sentencia a la bailarina al describirla como «ágil simio bailante» (Espinosa 2017: 103). Debe señalarse que la bailarina falleció el 23 de enero de 1931, por lo que Espinosa elabora un manifiesto personal basado en la muerte de la "reina» del ballet y, por consiguiente, el derrumbamiento de este, hecho que, en otro orden de cosas, nunca ha ocurrido. 
De la misma manera, igual que Pavlova representa lo decimonónico, se extrapola el ballet a toda la idiosincrasia y forma mentis que comparten y divulgan estos postulados. La cultura, la crítica o la poesía son objetivos también criticados por el autor, pues encierran valores caducos que se han de superar en la nueva hora. En este sentido, «Adiós al ballet» recuerda al manifiesto contra el teatro español de la época del número 21 de 1933 de Gaceta de Arte, en que, después de condenar a varios autores (como Muñoz Seca, los hermanos Álvarez Quintero, Linares Rivas, Sassone, Benavente, Martínez Sierra o Marquina), reclaman «un arte y un teatro vivo. humano, para el pueblo, nacido y devuelto a él y conectado a su historia y a su inquietud. que recoja valores de la elaboración de la vida contemporánea. o que ascienda a ese mundo irreal de la poesía» (Gaceta de arte 1933). Por eso, Espinosa condena rotundamente a aquellos poetas «balletianos» que perpetúan una estética anquilosada y unas ideas caducas según el arte nuevo que defendía. Como prócer, claro está, el autor apunta a Juan Ramón Jiménez y a sus continuadores, en su mayoría de la mal llamada Generación del 27, Jorge Guillén, Pedro Salinas y Federico García Lorca, entre otros.

Ante esta particular visión del ballet, metáfora de lo que se ha de superar, Espinosa propone nuevos caminos, ya que, de no ser así, se trataría de un manifiesto deficitario en sus propuestas de renovación. Para el autor, se trata de construir una nueva etapa histórica, pues, como bien indica, la muerte del ballet se puede igualar a la trascendencia del nacimiento de Jesús, la peregrinación de Mahoma o la conquista de Estambul. De esta manera, el manifiesto adquiere un valor aún más contestatario al plantear un nuevo ciclo histórico. El fin del reinado del ballet abre una nueva etapa. Por ello, insiste:

Levantemos un monumento al escupitajo, asesino del «ballet». Y otro al envés de los obreros de las seis de la tarde. Elogiemos el sudor mal oliente y el pelo encrespado y las axilas con centelleo. Ayudemos a bienenterrar pieles y gasas, romanzas sin peso y zapatos de charol. [...] Hay una urgencia [...] de arrastrar por todas las calles del siglo, de arrojar de azoteas espańolas, palacios italianos, pagodas indias, rascacielos yanquis y ultraburgos de Europa, el cadáver menos actual e indeseado: el cadáver del «ballet» que aún intentan conservar con óleos cansados los últimos artistas de un mundo que mira remozadamente hacia otra hora (Espinosa 2017: 104).

El ballet, por tanto, se convierte en una metáfora de la cosmovisión decimonónica, a la par que se configura como una sinécdoque: una expresión artística del xIx que representa al siglo en su totalidad. Por esa razón, el ballet, tan asociado al cisne, debe ser aniquilado de la misma manera en que lo formularon los postmodernistas predecesores de Espinosa. Recuérdese al poeta mexicano Enrique González Martínez, cuyo soneto «Tuércele el cuello al cisne de engañoso plumaje» manifiesta la necesidad de romper con los vestigios del arte finisecular y la óptica decimonónica. Con este manifiesto, el autor determina el destino del ballet, cuyo "cuello emplumado deviene cuerda roja» (Espinosa 2017: 105). Solo así, según su planteamiento, puede comenzar «el imperio de la antirrosa» (Espinosa 2017: 105), en donde se haya superado el ballet y el imaginario que había pervivido del siglo XIX, repleto de sílfides balletísticas, cisnes rubendaristas y rosas juanramonianas. 
Frente al ballet, siete meses después, Espinosa formula una nueva declaración de principios éticos con reminiscencias dancísticas. Si bien no se trata per se de un manifiesto, se podría clasificar de panegírico con cierto tono decadentista que, sin lugar a duda, vaticina el ciclo creativo en que el autor estaba introduciéndose: el surrealismo. El artículo «Bajo el signo de Demos. Elogio de Luisa Santana, tanguista de Las Palmas» ${ }^{20}$ podría entenderse como una réplica o continuación de "Adiós al ballet», en donde el autor va aún más allá y propone que "en esta hora de república y de democracia, de auge proletariado, de periclitaje de lo aristocrático, cantemos a la mujer sin hogar, a la templadora de Eros. Cantemos a una obrera de la noche, a una biznieta de Mariana Pineda, a una tornera monja del medievo» (Espinosa 2017: 157). Es decir, si Tomás Borrás (1931: 20) había visto en Ana Pavlova la síntesis de todas las mujeres, Espinosa sitúa como paradigma de su estética a la tanguista Luisa Santana, de Las Palmas de Gran Canaria. De esta manera, se desplaza el elitismo del ballet en aras de una paria de la danza que puede presentarse como epítome del proletariado o demos ('pueblo'), a la par que permite la identificación. De esta manera se entiende el sugerente principio del título del artículo «Bajo el signo de Demos», que recuerda a su reconocido trabajo Sobre el signo de Viera (1935).

Así pues, Luisa Santana se propone como el modelo espinosiano de feminidad y de sociedad, que se equipara a la trascendencia de su musa María Ana, que inspiró Oda a Maria Ana, primer premio de axilas sin depilar de 1930 (1931) y Crimen (1934). Pérez Corrales apunta que el apellido de la tanguista, Santana, integra al de su musa, Ana (Espinosa 2019: 159), un aliciente más para compararlas.

Pero, desde el punto de vista dancístico, el poeta abre un nuevo paradigma literario de bailarina para las vanguardias, que es insular, y a la vez se desvincula del exotismo de tinte colonial, por ejemplo, de Joséphine Baker. Como comenta Gómez Gutiérrez (2008: 578), a partir del Romanticismo, se elaboran varios esquemas nuevos de bailarinas que ahondan su tradición, por ejemplo, en fuentes bíblicas. En primer lugar, se encontraría la etérea Sílfide, surgida de un ballet homónimo de 1832, basado en un cuento de Charles Nodier. En segundo término, como patrón de bailarina romántica, se propaga Esmeralda de Nuestra Señora de París (1931), de Víctor Hugo. A continuación, habría que añadir el caso de Carmen de la novela homónima de Prosper Mérimée de 1845; cuya versión de ópera en 1875 de manos de Bizet afianzó la mirada exótica sobre la españolidad transida por la fatalidad que codificó las preferencias dancísticas en el extranjero ${ }^{21}$. Dentro de los esquemas del simbolismo sobresale la Fanfarlo, un nuevo esquema de bailarina española trágica, de la nouvelle publicada en 1847 por Charles Baudelaire. Desde los presupuestos

${ }^{20}$ Publicado el 4 de noviembre de 1931 en La Prensa y el 9 de noviembre del mismo año en El Pais.

${ }^{21}$ A finales del siglo Xıx, se popularizó en los escenarios franceses el género de la españolada, en donde funcionaban bien estos arquetipos. Posteriormente las bailarinas jugaron con estos esquemas y su proyección internacional, aunque reinventados desde otra óptica, como se observa en los Ballets Espagnols de la Argentina, que, a pesar de la brevedad de su existencia y su dilatada gira internacional, no llegó a pisar los teatros españoles. 
decandentistas, destaca la reinvención que en 1891 realizó Oscar Wilde de Salomé. Por último, Mallarmé y Valéry, en las obras ya citadas, proponen un prototipo de bailarina como metáfora, como parte de un lenguaje, una visión centrada en lo puro y platónico.

De toda esta genealogía, Espinosa no selecciona ningún arquetipo claro, sino que prefirió confeccionar uno propio que, como en el caso de la Carmen de Mérimée o la Fanfarlo baudelairiana, ahonda sus raíces en la autobiografía del autor. No obstante, sobre Luisa Santana proyecta Espinosa una mirada de fascinación semejante a la explorada por Ramón Gómez de la Serna en sus danzas de 1910 tras su regreso de la capital francesa, en donde Polaire y, sobre todo, Colette lo cautivaron. Luisa Santana entronca con esta genealogía al caracterizarse por la fatalidad, por un destino impreciso pero imaginable, ya que se mueve en el sórdido espacio de un cabaré portuario: «Ella ha de caer, trágicamente, una noche, bajo el puñal de un marinero ebrio o los fuertes brazos de un maduro cargador o el navajazo diestro de un majoso mancebo» (Espinosa 2017: 158). Además, representa la libertad y la seguridad femeninas que recuerdan a la protagonista de las piezas finiseculares: «Es ella la dueña de su frágil cuerpo de bronce. [...] Ella ha inventado la fábula que tejen sus pies y que dibujan sus manos. La noche le espera y le huye la mañana» (Espinosa 2017: 157); «ella va haciendo, día tras día, su novela. De la cual es protagonista, actriz, símbolo y autora" (Espinosa 2017: 158). Pero las dos grandes diferencias con todos estos imaginarios sobre las mujeres recaen en una atlanticidad con aires antidací$\operatorname{licos}^{22}$ y en la simbología popular, porque «mientras Luisa Santana baile, el equilibrio de una república no precisa cuidados. Su danza arrolla en sus giros ojos peligrosos y distrae con juegos de magia a jugadores de lo trágico» (Espinosa 2017: 158). Luisa Santana, por tanto, representa la nueva estética, la nueva sociedad, el nuevo mundo que anhela el autor. En definitiva, Luisa Santana se formula como bailarina «antiballetiana», "heroína de barrio marinero, signo matriarcal, temple de descarriados, Virgen de puerto atlántico, tanguista sideral de Las Palmas» (Espinosa, 2017: 158).

\section{CONCLUSIONES}

Tras este detallado análisis, se puede colegir que el tratamiento de la danza dentro de la producción escrita de Agustín Espinosa ocupa un espacio secundario, ya que se contabilizan pocos textos estructurados en torno a la propia idea de danza. No obstante, esta premisa no supone que, por ello, el arte coreográfico no adquiera una importancia contextual o no se hayan extraído nuevas perspectivas sobre la obra espinosiana. Al contrario, el presente estudio ofrece una profundización en los referentes y conocimientos dancísticos del autor, con los que se demuestra que el poeta

$22 \mathrm{El}$ autor ejecutó una reflexión en torno al mito de la princesa aborigen Dácil de Antonio de Viana y su evolución, en la que propone finalmente un contramito dacílico. El ensayo breve se publicó el 1 de mayo de 1932 bajo el título «La infantina de Nivaria» en La Prensa. 
estaba al tanto de la actualidad. Además, el análisis permite certificar la importancia cultural en la Edad de Plata de la disciplina artística, que, de una manera u otra, lleva a los escritores a tomar parte en debates y en elogios a figuras de la escena.

En cuanto al análisis específico de los textos, se aprecian estrategias recurrentes en las que el autor se acerca al arte dancístico, en ningún caso sin formular una pieza per se dancística como pantomimas coreográficas, números coreográficos dentro de su pieza teatral o libretos de ballet, entre otras formas ampliamente exploradas por escritores coevos. En primer lugar, destaca el uso reiterado de la danza para ejemplificar una época, de tal suerte que el tinerfeño establece continuamente silogismos entre expresiones dancísticas y la cosmovisión de una etapa. Por ello, el ballet o la bailarina de ópera son signos decimonónicos que rechaza Espinosa por representar la decadencia del sistema frente, por ejemplo, al charlestón o el jazz, que entrañan modernidad, renovación y nuevas ideas para los ańos veinte y treinta del pasado siglo. En segundo lugar, se percibe la inscripción de algunas imágenes retóricas dentro de una suerte de tradición que asocia la idea de movimiento con algunos elementos naturales, como el fuego o el viento, lo que al superponer la danza sobre ellos genera metáforas y símiles de gran expresividad. En tercer lugar, la estrategia con la que se puede rastrear más fácilmente los conocimientos espinosianos sobre la danza es, sin duda, las menciones que se hacen de espectáculos y artistas. A lo largo del artículo, se ha señalado la actualidad de los conocimientos del prosista, pero no cabe duda de que estos resultados son parciales al desconocer si realmente pudo disfrutarlos. Conjeturamos que, al menos de manera audiovisual, conoció a dichos referentes y, muy probablemente, en sus estancias madrileñas y parisinas pudiera asistir a algún espectáculo. Entre las referencias, destacan alusiones al ballet ruso (la bailarina de ballet Ana Pavlova, María Rasputín o el ballet Petruchka de los Ballets Russes), a bailarinas aclamadas por los vanguardistas (como Clotilde Sakharoff o Joséphine Baker) o a cuestiones españolas (como el bailaor Vicente Escudero o $E l$ amor brujo, probablemente por conocimiento del ballet). En último lugar, al combinarse las estrategias anteriores, en los artículos "Adiós al ballet» y «Bajo el signo de Demos. Elogio de Luisa Santana, tanguista de Las Palmas» se constata cómo, a través de la danza, se configura un manifiesto personal y una proclama del ideario ideológico, vital y estético del escritor, lo que demuestra la trascendencia que el arte coreográfico tiene como impresión del mundo y como imagen poética que el autor pervierte desde su óptica «antiballetiana». Por ello, tras este análisis, no resulta extraño que el creador de Crimen execrara el ballet por decimonónico y burgués, y que se dedicara a la admiración de aquella tanguista sideral de Las Palmas, símbolo del proletariado y el deseo. Para Espinosa ver bailar a Luisa Santana era un acto revolucionario en la hora última de las vanguardias. 


\section{BIBLIOGRAFÍA}

Álvarez Cañıbano, Antonio, e Yvan Nommick (eds.) (2000): Los Ballets Russes de Diaghilev y España, Madrid/Granada: Centro de Documentación de la Música y de la Danza del INAEM y Archivo Manuel de Falla.

Borrás, Tomás (1931): Tam tam. Pantomimas. Bailetes. Cuentos coreográficos. Mimodramas, Madrid: Compañía Iberoamericanas de Publicaciones.

Coello Hernández, Alejandro (2019): «Sueños para una nueva danza española: la dramaturgia de El desertor (1930), de Felipe Ximénez de Sandoval», Diablotexto 6, 41-60. URL: https://ojs. uv.es/index.php/diablotexto/article/view/16753.

Escudero, Vicente (1947): Mi baile, Barcelona: Montaner y Simón.

Espinosa, Agustín (2017): Oda a María Ana, primer premio de axilas sin depilar de 1930. Textos 19301931, ed. José Miguel Pérez Corrales, Tenerife: Insoladas.

Espinosa, Agustín (2018a): Media hora jugando a los dados. Textos 1932-1933, ed. José Miguel Pérez Corrales, Tenerife: Insoladas.

Espinosa, Agustín (2018b): Crimen. Textos 1934-1936. ed. José Miguel Pérez Corrales, Tenerife: Insoladas.

Espinosa, Agustín (2019): Lancelot, $28^{\circ}-7^{\circ}$. Textos 1927-1929, ed. José Miguel Pérez Corrales, Tenerife: Insoladas.

GACETA DE ARTE (1933): «10 manifiesto de g.a. Tema: contra el actual teatro español», Gaceta de arte 21, noviembre, 3 .

García de Mesa, Roberto (2012): El teatro de vanguardia en Canarias, Tenerife: Idea.

Gil-Albert, Juan (1930): «Ana Pavlova. Último baluarte del zarismo», La Gaceta Literaria 75, febrero, 9 .

Gómez de la Serna, Ramón (1931): Ismos, Madrid: Biblioteca Nueva, Col. Javier Fernández.

Gómez Gutiérrez, Beatriz (2008): Les mythes et leurs métamorphoses dans l'oeuvre d'Agustín Espinosa (1897-1936) [tesis doctoral], París: Université Paris IV Sorbonne.

HeRALDO DE MADRID (2017): «Banquete a Picasso», Heraldo de Madrid, 5 de junio, 2.

Mallarmé, Stéphane (1897): Divagations. París: Eugène Fasquelle éditeur.

Martínez del Fresno, Beatriz (2016): «El alma rusa en el imaginario español de la Edad de Plata: resonancias musicales y coreográficas (1914-1923)», Cuadernos de Historia Contemporánea 38, 31-56.

Murga Castro, Idoia (2017): Escenografia de la danza en la Edad de Plata (1916-1936), Madrid: CSIC.

Ortega y Gasset, José (2009): La deshumanización del arte. Ideas sobre la novela, Madrid: Castalia.

Rivas Cherif, Cipriano de (1922): «La danza clásica y el baile castizo», Los lunes del Imparcial 19684, 5 de marzo, 2. 